\title{
Reduction of Nitrite by Neisseria gonorrhoeae
}

\author{
JOAN S. KNAPP \\ Neisseria Reference Laboratory and Department of Medicine ZA-20, University of Washington, \\ Seattle, Washington 98195
}

\begin{abstract}
A total of 112 Neisseria gonorrhoeae strains representing protein I serogroups WI, WII, and WIII and six auxotypes were tested for their ability to reduce nitrite. All strains reduced $0.001 \%$ (wt/vol) potassium nitrite $\left(\mathrm{KNO}_{2}\right)$ within $24 \mathrm{~h}$ and $0.01 \%$ (wt/vol) $\mathrm{KNO}_{2}$ within $48 \mathrm{~h}$. None of the strains reduced $0.1 \%$ (wt/vol) $\mathrm{KNO}_{2}$ even after incubation at $37^{\circ} \mathrm{C}$ for 5 days, and the strains could not be cultured from these tests after incubation for $24 \mathrm{~h}$. Thus, all of the $N$. gonorrhoeae strains tested were nitrite sensitive but were able to reduce subtoxic concentrations of $\mathrm{KNO}_{2}$. Nitrite reduction is a species characteristic for N. gonorrhoeae.
\end{abstract}

Nitrite reduction is included as a differential test for the classification of Neisseria spp. and Branhamella catarrhalis $(7,9)$. Nitrite is reduced by all human Neisseria spp., with the possible exception of Neisseria gonorrhoeae strains and strains of some serogroups of Neisseria meningitidis $(6,7)$. In 1961, Berger showed that neither $N$. gonorrhoeae strains nor some $N$. meningitidis strains could reduce $0.1 \%(\mathrm{wt} / \mathrm{vol})$ nitrite (1). While characterizing Neisseria cinerea strains in 1962, Berger and Paepcke demonstrated that although most $N$. cinerea strains reduced $0.1 \%$ (wt/vol) nitrite, 3 of 28 strains $(11 \%)$ did not reduce $0.1 \%$ (wt/vol) nitrite but reduced $0.01 \%(\mathrm{wt} / \mathrm{vol})$ nitrite (3). Berger subsequently reevaluated nitrite reduction by $N$. gonorrhoeae and $N$. meningitidis (2). All five strains of $N$. gonorrhoeae tested reduced $0.01 \%$ (wt/vol) nitrite. However, among $58 N$. meningitidis strains tested, only strains of serogroups $A, D$, and $Y$ could reduce $0.01 \%(\mathrm{wt} / \mathrm{vol})$ nitrite, whereas strains of serogroups B, C, $X$, and $Z$ could not. Unaware of the study of Berger (2), coworkers and I rediscovered that $N$. gonorrhoeae strains could reduce nitrite while we were evaluating nitrite reduction as a test for differentiating between clinical isolates of $N$. cinerea and $N$. gonorrhoeae (6). Since nitrite reduction by $N$. meningitidis strains was serogroup specific and three serogroups (serogroups WI, WII, and WIII) belonging to two protein I molecular types are recognized for $N$. gonorrhoeae $(10,11)$, I reevaluated nitrite reduction by $N$. gonorrhoeae strains to determine whether this is a species characteristic.

(The results were reported in part at the Annual Meeting of the American Society for Microbiology, New Orleans, La., March 1983 [J. S. Knapp, Abstr. Annu. Meet. Am. Soc. Microbiol. 1983, D27, p. 63].)

\section{MATERIALS AND METHODS}

Strains. A total of 112 N. gonorrhoeae strains were tested. The laboratory strains included the taxonomic type strain, strain NRL 30010 (= ATCC 19424), 15 serogroup WI, WII, and WIII serological reference strains (11), strains NRL 905 $\left(\mathrm{AHU}^{-} / \mathrm{WI}\right)$ and NRL 8038 (F62; Prö/WII), and strains isolated in The Philippines (4 strains), Europe (5 strains), and Africa (18 strains, 4 of which were $\beta$-lactamase positive). Also included were 67 cervical and urethral isolates from women and men attending an Adult Medicine Clinic in Seattle, Wash. The clinical isolates represented six auxotypes and serogroups WI, WII, and WIII (Table 1). Five Neisseria mucosa strains were compared with the $N$. gonorrhoeae strains in these tests. The strains were grown on supplemented GC base medium (Difco Laboratories, Detroit, Mich.), as described previously (13). Strains were stored at $-70^{\circ} \mathrm{C}$ in a solution of $50 \%$ heat-inactivated $\left(56^{\circ} \mathrm{C}\right.$,
$30 \mathrm{~min}$ ) gamma-globulin-free horse serum (GIBCO Laboratories, Grand Island, N.Y.) in tryptic soy broth (Difco).

Auxotyping and serogrouping of clinical isolates of $\boldsymbol{N}$. gonorrhoeae. The isolates were auxotyped on Catlins NEDA defined medium, as described previously $(4,5)$. Serogrouping was performed by using group-specific polyclonal antisera in a coagglutination test, as described previously (11).

Nitrite reduction tests. All $N$. gonorrhoeae and $N$. mucosa strains were tested in 1-ml volumes of tryptic soy broth containing $0.1,0.01$, and $0.001 \%$ (wt/vol) $\mathrm{KNO}_{2}$ in Pyrex tubes ( 16 by $100 \mathrm{~mm}$; Corning Glass Works, Corning, N.Y.). The tests were inoculated in triplicate with loopfuls of an overnight culture grown on supplemented GC base agar at $37^{\circ} \mathrm{C}$ for $24 \mathrm{~h}$ in $5 \% \mathrm{CO}_{2}$. A loopful of broth was removed from each test in $0.001 \%$ (wt/vol) $\mathrm{KNO}_{2}$, plated onto supplemented GC base medium, and incubated at $37^{\circ} \mathrm{C}$ for $24 \mathrm{~h}$ to confirm that positive tests resulted from $N$. gonorrhoeae activity. Similarly, each test in $0.1 \%$ (wt/vol) $\mathrm{KNO}_{2}$ was tested to determine whether $N$. gonorrhoeae strains were viable after incubation at $37^{\circ} \mathrm{C}$ for $24 \mathrm{~h}$. Tests for residual nitrite were made after incubation at $37^{\circ} \mathrm{C}$ without $\mathrm{CO}_{2}$ for 24 $\mathrm{h}, 48 \mathrm{~h}$, and 5 days, as described previously (12). Tests were recorded as positive only if nitrite was reduced completely.

\section{RESULTS AND DISCUSSION}

In accordance with the findings of Berger (1), all five $N$. mucosa strains reduced $0.1 \%$ (wt/vol) $\mathrm{KNO}_{2}$ completely within $24 \mathrm{~h}$. In contrast, none of the $112 \mathrm{~N}$. gonorrhoeae strains reduced $0.1 \%(\mathrm{wt} / \mathrm{vol}) \mathrm{KNO}_{2}$ even after incubation for 5 days. All $N$. gonorrhoeae strains, irrespective of auxotype or serogroup, reduced $0.01 \%$ (wt/vol) $\mathrm{KNO}_{2}$ within $48 \mathrm{~h}$ and $0.001 \%$ (wt/vol) $\mathrm{KNO}_{2}$ within $24 \mathrm{~h}$. Thus, all $N$. gonorrhoeae strains were nitrite sensitive, but reduced subinhibitory concentrations of nitrite.

Pure cultures of $N$. gonorrhoeae were isolated from all tests in medium which had contained $0.001 \%$ (wt/vol) $\mathrm{KNO}_{2}$. In contrast, $N$. gonorrhoeae was not isolated from tests in medium that contained $0.1 \%(\mathrm{wt} / \mathrm{vol}) \mathrm{KNO}_{2}$ and was tested after $24 \mathrm{~h}$ of incubation. Thus, the $N$. gonorrhoeae strains were not only unable to reduce, but were killed by, $0.1 \%$ (wt/vol) $\mathrm{KNO}_{2}$.

Detection of nitrite reduction by bacterial species is routinely made in a nutrient medium containing $0.1 \%(\mathrm{wt} / \mathrm{vol})$ $\mathrm{KNO}_{2}(12)$. Strains are tested in 4-ml volumes of medium in $15-$ by $125-\mathrm{mm}$ tubes. Deep broth tubes are recommended because nitrite reduction occurs only in the absence of oxygen (8), and the ratio of surface area to volume is kept small to prevent oxygen from diffusing into the medium and inhibiting nitrite reduction. In this study, nitrite reduction 
TABLE 1. Characteristics of 67 clinical isolates of $N$. gonorrhoeae tested for their ability to reduce nitrite

\begin{tabular}{lrrrcrc}
\hline & \multicolumn{5}{c}{ Wo. with auxotype $^{b}$} \\
\cline { 2 - 6 } & AHU $^{-}$ & Proto & Pro $^{-}$ & Arg $^{-}$ & $\begin{array}{l}\text { Pro }^{-} \\
\text {Arg }^{-}\end{array}$ & PAU $^{-}$ \\
WI & 5 & 2 & 1 & & & \\
WII & & 39 & 10 & 1 & 1 & 2 \\
WIII & 4 & & & 1 & 1 \\
\hline
\end{tabular}

a Serogroups WII and WIII are subgroups which belong to the Protein IB molecule group, which is distinct from the protein $1 \mathrm{~A}$ molecule group to which serogroup WI strains belong. $(10,11)$.

${ }^{b} \mathrm{AHU}^{-}$, Arginine, hypoxanthine, and uracil requiring; Proto, no requirements; $\mathrm{Pro}^{-}$, proline requiring; $\mathrm{Arg}^{-}$, arginine requiring; $\mathrm{PAU}^{-}$, proline, arginine, and uracil requiring. All strains required cystine-cysteine for growth.

was detected easily in 1-ml volumes of medium in $12-$ by $72-$ mm tubes. I postulated that $N$. gonorrhoeae cells rapidly reduced any dissolved oxygen in the medium and that cells near the medium surface continued to reduce any dissolving oxygen, thus permitting nitrite reduction to occur in the anoxygenic medium.

Although $N$. gonorrhoeae strains reduced subinhibitory nitrite concentrations, they were inhibited by, and could not reduce, the $0.1 \%$ (wt/vol) $\mathrm{KNO}_{2}$ routinely recommended for nitrite reduction tests (12). The results obtained in this study emphasize the need to modify routinely recommended tests where necessary in order to determine whether nitritesensitive bacterial species can reduce nitrite at subinhibitory concentrations. Obviously, this applies not only to descriptions of new taxa, but also to reevaluation of well-established species, such as $N$. gonorrhoeae. Consequently, I recommend that nitrite reduction tests be made in a broth medium containing either 0.01 or $0.001 \%$ (wt/vol) $\mathrm{KNO}_{2}$ in order to detect nitrite reduction by those bacterial species that are unable to reduce $0.1 \%$ (wt/vol) $\mathrm{KNO}_{2}$.

\section{ACKNOWLEDGMENT}

This research was supported by Public Health Service research grant AI-12192 from the National Institutes of Health.

\section{LITERATURE CITED}

1. Berger, U. 1961. Reduktion von Nitrat und Nitrit durch Neisseria. Z. Hyg. 148:45-50.

2. Berger, U. 1970. Untersuchungen zur Reduktion von Nitrat und Nitrit durch Neisseria gonorrhoeae und Neisseria meningitidis. Z. Med. Mikrobiol. Immunol. 156:86-89.

3. Berger, U., and E. Paepcke. 1962. Untersuchungen uber die asaccharolytischen Neisserien des menschlichen Nasopharynx. Arch. Hyg. Infektionskr. 148:269-281.

4. Catlin, B. W. 1973. Nutritional profiles of Neisseria gonorrhoeae, Neisseria meningitidis, and Neisseria lactamica in chemically defined media and the use of growth requirements for gonococcal typing. J. Infect. Dis. 128:178-194.

5. Knapp, J. S., and K. K. Holmes. 1975. Disseminated gonococcal infections caused by Neisseria gonorrhoeae with unique nutritional requirements. J. Infect. Dis. 132:204-208.

6. Knapp, J. S., P. A. Totten, M. H. Mulks, and B. H. Minshew. 1984. Characterization of Neisseria cinerea: a nonpathogenic Neisseria sp. isolated on Martin-Lewis medium selective for pathogenic Neisseria spp. J. Clin. Microbiol. 19:63-67.

7. Morello, J. A., and M. Bohnnoff. 1980. Neisseria and Branhamella, p. 111-130. In E. H. Lennette, A. Balows, W. J. Hausler, Jr., and J. P. Truant (ed.), Manual of clinical microbiology, 3rd ed. American Society for Microbiology, Washington, D.C.

8. Payne, W. J. 1973. Reduction of nitrogenous oxides by microorganisms. Bacteriol. Rev. 37:409-452.

9. Reyn, A. 1974. Genus I. Neisseria Trevisan, p. 428-432. In R. E. Buchanan and N. E. Gibbons (ed.), Bergey's manual of determinative bacteriology, 8th ed. The Williams \& Wilkins Co., Baltimore.

10. Sandstrom, E. G., C. K. S. Chen, and T. M. Buchanan. 1982. Serology of Neisseria gonorrhoeae: Coagglutination serogroups WI and WII/III correspond to different outer membrane protein I molecules. Infect. Immun. 38:462-470.

11. Sandstrom, E. G., and D. Danielsson. 1980. Serology of Neisseria gonorrhoeae with coagglutination. Acta Pathol. Mickrobiol. Scand. Sect. B 88:27-38.

12. Vera, H. D., and D. A. Power. 1980. Culture media, p. 965-999. In E. H. Lennette, A. Balows, W. J. Hausler, Jr., and J. P. Truant (ed.), Manual of clinical microbiology, 3rd ed. American Society for Microbiology, Washington, D.C.

13. White, L. A., and D. S. Kellogg, Jr. 1965. Neisseria gonorrhoeae identification in direct smears by a fluorescent antibody counterstain method. Appl. Microbiol. 13:171-174. 